\title{
Synthesis and Characterization of Gold(I) and Gold(III) Complexes Derived from Benzimidazolin-2-ylidene Ligands
}

\begin{tabular}{|c|c|}
\hline Journal: & Zeitschrift für Anorganische und Allgemeine Chemie \\
\hline Manuscript ID: & zaac. 201000234.R1 \\
\hline Wiley - Manuscript type: & Article \\
\hline $\begin{array}{r}\text { Date Submitted by the } \\
\text { Author: }\end{array}$ & 01-Jul-2010 \\
\hline Complete List of Authors: & $\begin{array}{l}\text { Hahn, Ekkehardt; Westfaelische Wilhelms-Universitaet Muenster, } \\
\text { Institut fuer Anorganische Chemie } \\
\text { Jahnke, Mareike; Westfaelische Wilhelms-Universitaet Muenster, } \\
\text { Institut fuer Anorganische Chemie } \\
\text { Pape, Tania; Westfaelische Wilhelms-Universitaet Muenster, Institut } \\
\text { fuer Anorganische Chemie }\end{array}$ \\
\hline Keywords: & N-Heterocyclic Carbene, Gold, Oxidation, Molecular Structure \\
\hline
\end{tabular}

\section{scholarONE" \\ Manuscript Central}




\title{
ARTICLE
}

\author{
DOI: 10.1002/zaac.200((will be filled in by the editorial staff))
}

\section{Synthesis and Characterization of Gold(I) and Gold(III) Complexes Derived from Benzimidazolin-2-ylidene Ligands}

\author{
Mareike C. Jahnke, ${ }^{[\mathrm{a}]}$ Tania Pape ${ }^{[\mathrm{a}]}$ and F. Ekkehardt Hahn*,[a]
}

In memory of Prof. Dr. Herbert Schumann

Keywords: N-Heterocyclic Carbene; Gold; Oxidation, Molecular Structures

Substitution of the chloro ligand in $\left(N, N^{\prime}\right.$-dialkylbenzimidazolin-2ylidene)gold(I) chlorides (alkyl = methyl, ethyl, propyl, butyl) succeeded by treatment of the gold chloride complexes with lithium bromide in acetone leading to the gold complexes of the type $[\mathrm{AuBr}(\mathrm{L})]$ 1-4. Furthermore, the $\mathrm{Au}-\mathrm{C}_{\text {carbene }}$ bond in complexes 1-4 is inert towards a change of the oxidation state of the metal

\section{Introduction}

Today, N-heterocyclic carbenes (NHCs) are well established ligands in organometallic chemistry [1]. This development rests on the easy access to differently substituted NHCs making them a good alternative to phosphines in the design of new organometallic catalysts [1, 2]. The facile access to NHCs is complemented by the superior $\sigma$-donor properties of the carbene ligands compared to the most basic phosphines [3] leading to a remarkable stability of the carbene complexes against air, moisture, heat and oxidizing conditions [1]. Recently, poly-NHC ligands have also been used as building blocks for metallosupramolecular structures. Linear di- [4] as well as tri- or tetra-NHC ligands [5] have been employed for the generation of molecular rectangles or cylindrical molecules which provide cavities suitable as host for guest molecules during a catalytic reaction [6].

A large portion of all known NHC complexes contain a group 9 or 10 transition metal [2a, 7] or ruthenium [8] as the metal center. In addition, many silver carbene complexes [9] have been prepared after Wang and Lin [10] reported in 1998 the very useful carbene transfer reaction utilizing silver NHC complexes. Today, this carbene transfer reaction has developed into a versatile and well established procedure for the synthesis of transition metal NHC complexes [9].

* Prof. Dr. F. Ekkehardt Hahn Fax: 0049-251-833-3110

E-Mail: fehahn@uni-muenster.de

[a] Institut für Anorganische und Analytische Chemie Westfälische Wilhelms-Universität Münster

Corrensstraße 28/30

48149 Münster, Germany center. Complexes 1-4 have been oxidized chemically with elemental bromine leading to the gold(III) carbene complexes of the type $\left[\mathrm{AuBr}_{3}(\mathrm{~L})\right] \mathbf{5 - 8}$. The molecular structures of the gold(I) complexes 1, $\mathbf{2}$ and $\mathbf{4}$ exhibiting a linear topology are presented together with the two molecular structures of the square-planar gold(III) complexes $\mathbf{6}$ and $\mathbf{8}$.

Gold NHC complexes have only recently attracted interest, although the preparation of such complexes has been reported as early as 1998 [10]. This development supports the recent resurgence of interest in gold catalyzed reactions [11] which in turn has initiated a search for new gold NHC complexes [12]. Today gold NHC complexes are used as pharmaceuticals [13], in photophysical devices [14], and as catalysts for selected transformations in homogeneous catalysis [15].

The inertness of the $\mathrm{Au}-\mathrm{C}_{\mathrm{NHC}}$ bond during substitution reactions at linear $[\mathrm{AuX}(\mathrm{NHC})]$ complexes was noted by Wang and Lin as early as 1999 [16]. Ligand X in complexes of the type $[\mathrm{AuX}(\mathrm{NHC})]$ can be substituted for halides [16, 17], nitrogen- [18, 19] and phosphorous-donors [4a, 19] or even hydroxide [20]. It has also been shown, that the $\mathrm{Au}-\mathrm{C}_{\text {carbene }}$ bond is not affected if gold(I) NHC complexes bearing unsaturated imidazolin-2-ylidene or saturated imidazolidin-2-ylidene ligands are oxidized with bromine [21] or chlorine [22] to give gold(III) complexes of the type $\left[\mathrm{AuX}_{3}(\mathrm{~L})\right] \quad(\mathrm{L}=$ imidazolin-2-ylidene or imidazolidin-2ylidene; $\mathrm{X}=\mathrm{Br}, \mathrm{Cl})$.

Most known gold NHC complexes bear the ubiquitous unsaturated imidazolin-2-ylidenes as carbene ligands, while there are only a few examples for gold complexes bearing benzimidazolin-2-ylidenes [10, 16, 20a-b, 23, 24]. We have been interested in the synthesis and properties of transition metal complexes with benzimidazolin-2-ylidenes for several years [25]. Recently we reported the synthesis and some characteristic properties of gold(I) complexes of the type [AuCl(L)] bearing $N, N^{\prime}$-dipropyl- or $N, N^{\prime}$-dibutylsubstituted benzimidazolin-2-ylidene ligands [26].

Here we describe the synthesis of gold(I) complexes with $N, N$ '-dialkylated benzimidazolin-2-ylidene ligands and their oxidation with elemental bromine to the gold(III) complexes. The molecular structures of linear gold(I) NHC complexes will be discussed together with the molecular structures of square-planar gold(III) complexes. 


\section{Results and Discussion}

Gold(I) complexes of the type [AuCl(NHC)] (Scheme 1) were prepared as described $[16,26]$. The oxidation of these gold(I) chloride complexes with bromine would lead to a mixture of complexes with bromo and chloro ligands. We therefore performed a halide exchange by treatment of the gold(I) chloride complexes with a tenfold excess of lithium bromide in acetone (Scheme 1) following the procedure described by Nolan et al. [21]. The gold(I) bromide complexes 1-4 were obtained in good yields (86-98\%) after purification. Although the synthesis of complexes $\mathbf{1}$ and $\mathbf{2}$ has already been reported [16], we have listed them here, since we are providing additional analytical data.<smiles></smiles>

$1: \mathrm{R}=\mathrm{Me}$

2: $\mathrm{R}=\mathrm{Et}$

3: $\mathrm{R}=\mathrm{Pr}$

4: $\mathrm{R}=\mathrm{Bu}$

Scheme 1. Synthesis of the gold(I) bromide complexes 1-4 by substitution of the chloro ligand.

The ${ }^{13} \mathrm{C}$ NMR spectra of gold complexes 1-4 exhibit the resonance for the carbene carbon atom in the narrow range of $\delta$ 180.5-181.2. Compared to the resonances of the carbene carbon atoms of the parent gold(I) chloride complexes $(\delta 178-179)$ [26] a slight downfield shift $(\Delta \delta 2-$ 3 ) was observed upon the halide exchange, while all other resonances in the ${ }^{1} \mathrm{H}$ and ${ }^{13} \mathrm{C}$ NMR spectra remain nearly unchanged. Crystals of 1, 2 and 4, which were suitable for X-ray diffraction studies, have been obtained by slow diffusion of diethyl ether into dichloromethane solutions of the individual complexes. The molecular structures of complexes 1, 2 and $\mathbf{4}$ are depicted in Figures 1 and 2 and selected bond parameters are listed in Table 1.
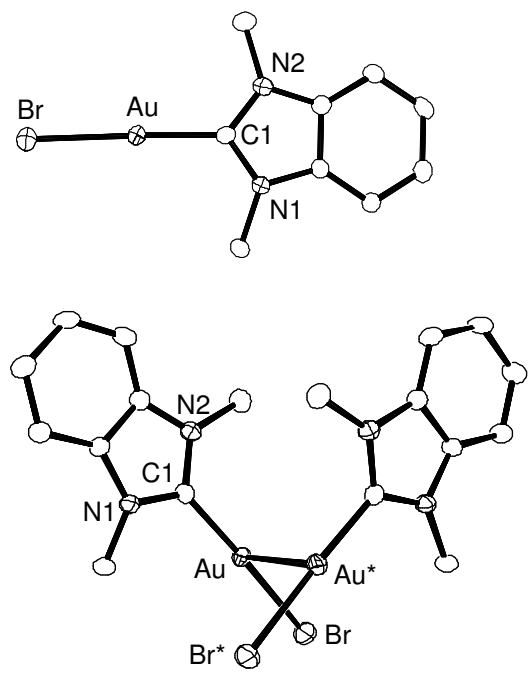

Figure 1. Molecular structure of the gold(I) complexes 1 (top) and drawing of the dinuclear species formed by $\mathrm{Au} \cdots \mathrm{Au}$ interactions (bottom). Ellipsoids are drawn at the $50 \%$ probability level. Hydrogen atoms are omitted for clarity.
Complexes $\mathbf{1}$ and $\mathbf{4}$ reside on general positions in the unit cell, while complex $\mathbf{2}$ resides on a twofold axis passing through atoms $\mathrm{Br}, \mathrm{Au}$ and $\mathrm{C} 1$. As expected, complexes 1, 2, and 4 exhibit a linear coordination geometry. Two molecules of $\mathbf{1}$ form a dinuclear species via intermolecular $\mathrm{Au} \cdots \mathrm{Au}$ interactions [27] ( $\mathrm{Au} \cdots \mathrm{Au} 3.1179(3) \AA$, Figure 1, bottom). A similar aurophilic interaction ( $\mathrm{Au} \cdots \mathrm{Au} 3.1216(4)$ $\AA$ ) was found for $\mathbf{4}$ but not for 2 .

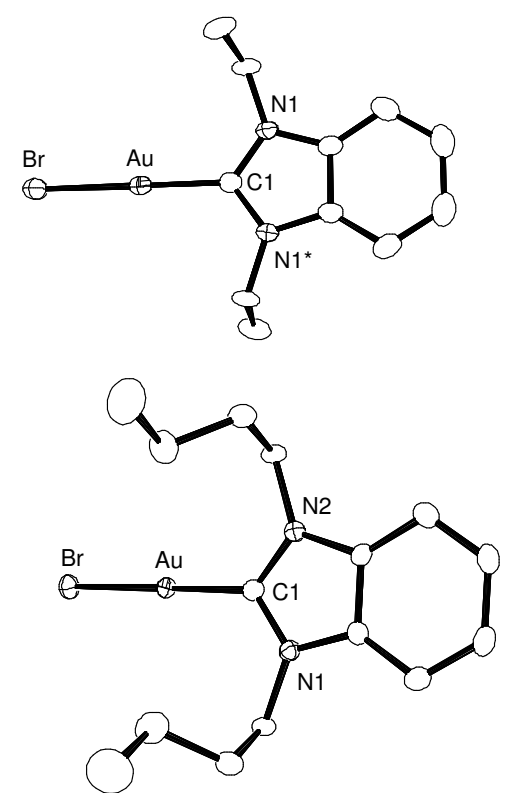

Figure 2. Molecular structures of the gold(I) complexes 2 (top) and 4 (bottom). Atoms $\mathrm{Au}, \mathrm{Br}$, and $\mathrm{C} 1$ of complex 2 lie on a crystallographic twofold axis. Ellipsoids are drawn at the $50 \%$ probability level. Hydrogen atoms are omitted for clarity.

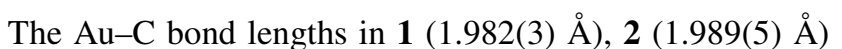
and 4 (1.994(3) $\AA$ ) are nearly identical to the $\mathrm{Au}-\mathrm{C}$ separations in the parent monocarbene gold(I) chloride complexes of the type $[\mathrm{AuCl}(\mathrm{L})]$ with $\mathrm{L}=$ benzimidazolin2-ylidene (Au-C 1.969(6)-2.01(3) ̊) [16, 23, 26]. These bond distances are also very close in magnitude to the values observed for $\mathrm{Au}-\mathrm{C}$ bonds found in complexes of the type [AuBr(imidazolin-2-ylidene)] (1.975 $\AA$ ) [21]. The Au$\mathrm{Br}$ bond lengths in $\mathbf{1}, \mathbf{2}$, and $\mathbf{4}$ also fall in the range previously observed for complexes of the type [AuBr(NHC)] [21]. As expected and previously observed for the parent $[\mathrm{AuCl}(\mathrm{NHC})]$ complexes [16, 23, 26], complexes 1, 2, and 4 exhibit an almost linear $\mathrm{C}-\mathrm{Au}-\mathrm{Br}$ bond. The $\mathrm{N}-\mathrm{C}_{\text {carbene }}-\mathrm{N}$ bond angles in the $\operatorname{gold}(\mathrm{I})$ complexes are slightly enlarged in comparison to the free benzimidazolin-2-ylidenes $\left(\mathrm{N}-\mathrm{C}_{\text {carbene }}-\mathrm{N} \approx 104^{\circ}\right)$ [28].

Table 1. Selected bond lengths $(\AA)$ and angles (deg) in complexes $\mathbf{1}, \mathbf{2}$, and 4.

\begin{tabular}{llll}
\hline Compounds & $\mathbf{1}$ & $\mathbf{2}$ & $\mathbf{4}$ \\
\hline Bond lengths & & & \\
$\mathrm{Au}-\mathrm{C} 1$ & $1.982(3)$ & $1.989(5)$ & $1.994(3)$ \\
$\mathrm{Au}-\mathrm{Br}$ & $2.4083(4)$ & $2.3910(7)$ & $2.4065(4)$ \\
$\mathrm{N} 1-\mathrm{C} 1$ & $1.352(4)$ & $1.345(4)$ & $1.343(4)$ \\
$\mathrm{N} 2-\mathrm{C} 1$ & $1.354(4)$ & - & $1.360(4)$ \\
$\mathrm{Au} \cdots \mathrm{Au} *$ & $3.1179(3)$ & - & $3.1216(4)$ \\
\hline $\mathrm{B}$ ond angles & & & \\
$\mathrm{C} 1-\mathrm{Au}-\mathrm{Br}$ & $177.75(10)$ & 180.0 & $179.30(9)$ \\
$\mathrm{N} 1-\mathrm{C} 1-\mathrm{N} 2 /$ & $106.3(3)$ & $107.5(4)$ & $106.8(3)$ \\
$\mathrm{N} 1-\mathrm{C} 1-\mathrm{N} 1 *$ & & & \\
\hline
\end{tabular}


Reaction of the gold complexes 1-4 with elemental bromine in dichloromethane gave the orange gold(III) complexes of the type $\left[\mathrm{AuBr}_{3}(\mathrm{NHC})\right] \mathbf{5 - 8}$ with $\mathrm{NHC}=$ $N, N^{\prime}$-dialkylated benzimidazolin-2-ylidene ligands in good yields (82-89\%, Scheme 2). The ${ }^{13} \mathrm{C}$ NMR spectra of the gold(III) complexes 5-8 show the resonances of the carbene carbon atoms in the range of $\delta 146.6-149.7$. These values represent an upfield shift $(\Delta \delta 31-35)$ of the $\mathrm{C}_{\text {carbene }}$ resonance upon oxidation of gold(I) to gold(III). This strong upfield shift is surprising when compared to the downfield shift of $\Delta \delta$ 1-2 observed for the carbon atoms of the aromatic ring upon the gold(I) $\rightarrow$ gold(III) oxidation. The resonances observed for $\mathrm{C}_{\text {carbene }}$ in $\mathbf{5}-\mathbf{8}$, however, resemble the values found for the $\mathrm{N}-\mathrm{CH}-\mathrm{N}$ resonances in the parent benzimidazolium salts $(\delta$ 141-144) [25a-c, 25e]. The upfield shift of the $\mathrm{C}_{\text {carbene }}$ resonance upon the $\operatorname{gold}(\mathrm{I}) \rightarrow \operatorname{gold}(\mathrm{III})$ oxidation has been observed for related $\left[\mathrm{AuX}_{3}(\mathrm{NHC})\right]$ complexes bearing imidazolin-2-ylidene or imidazolidin-2-ylidene ligands [21, 22, 29] and some authors have tried to explain this observation with the higher Lewis acidity of gold(III) in comparison to gold(I) [21].<smiles></smiles><smiles></smiles>

1,5: $\mathrm{R}=\mathrm{Me}$

2, 6: $R=E t$ 3, 7: $\mathrm{R}=\mathrm{Pr}$ 4, 8: $R=B u$

Scheme 2. Oxidation of the gold(I) complexes 1-4 with bromine to give the gold(III) complexes 5-8.

Crystals of $\mathbf{6}$ and $\mathbf{8}$ suitable for X-ray diffraction studies have been obtained by slow diffusion of diethyl ether into $\mathrm{dmf}(\mathbf{6})$ or dichloromethane $(\mathbf{8})$ solutions, respectively, of the complexes. Complex 8 crystallized as $\mathbf{8} \cdot 0.5 \mathrm{CH}_{2} \mathrm{Cl}_{2}$ with two formula units in the asymmetric unit. The two molecules of $\mathbf{8}$ in the asymmetric unit exhibit essentially identical metric parameters. Only one of these molecules is depicted in Figure 2 together with the molecular structure of 6. Selected bond parameters are summarized in Table 2.

The gold(III) complexes $\mathbf{6}$ and $\mathbf{8}$ feature the expected square-planar coordination geometry. The $\mathrm{Au}-\mathrm{C}$ bonds in 6 (2.003(4) $\AA$ ) and in the two molecules in $8 \cdot 0.5 \mathrm{CH}_{2} \mathrm{Cl}_{2}$ $(2.009(4) \AA)$ are similar in lengths to the equivalent bond distances observed in gold(III) complexes of the type $\left[\mathrm{AuBr}_{3}(\mathrm{NHC})\right] \quad(\mathrm{NHC}=$ imidazolin-2-ylidene or imidazolidin-2-ylidene) (Au-C 2.002(6)-2.052(6) Å) [21, 29]. The $\mathrm{Au}-\mathrm{C}$ distances are very similar in the gold(I) $(\mathbf{1}, \mathbf{2}$ 4) and the gold (III) complexes $\mathbf{6}$ and $\mathbf{8}$. The oxidation state of the gold atom apparently bears no significance for the $\mathrm{Au}-\mathrm{C}$ bond lengths. Due to the trans effect of the carbene donor the $\mathrm{Au}-\mathrm{Br}_{\text {trans }}$ bonds in $6(2.4465(4) \AA)$ and 8. $0.5 \mathrm{CH}_{2} \mathrm{Cl}_{2}(2.4521(5) \AA$ and $2.4519(5) \AA)$ are longer than the $\mathrm{Au}-\mathrm{Br}_{\text {cis }}$ bonds $(2.4107(5)-2.4276(4) \AA)$. These parameters match the equivalent values observed for related gold(III) monocarbene complexes [21, 29]. The $\mathrm{Au}-\mathrm{Br}_{\text {trans }}$ bond distances in $\mathbf{6}$ and $\mathbf{8} \cdot 0.5 \mathrm{CH}_{2} \mathrm{Cl}_{2}$ are significantly longer than the $\mathrm{Au}-\mathrm{Br}$ distances in $\mathbf{1}(2.4083(4) \AA), 2$ (2.3910(7) $\AA$ ), and 4 (2.4065(4) А) (Table 1).
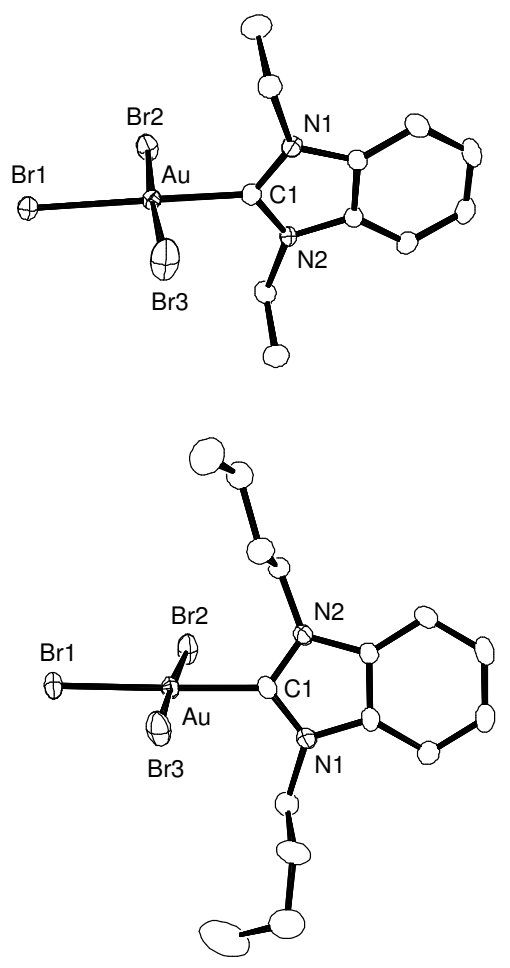

Figure 3. Molecular structures of the gold(III) complexes 6 (top) and $\mathbf{8}$ in $\mathbf{8} \cdot \mathrm{CH}_{2} \mathrm{Cl}_{2}$ (bottom). Ellipsoids are drawn at the $50 \%$ probability level and hydrogen atoms have been omitted for clarity.

Table 2. Selected bond lengths ( $\AA$ ) and angles (deg) for $\mathbf{6}$ and 8. $0.5 \mathrm{CH}_{2} \mathrm{Cl}_{2}$.

\begin{tabular}{|c|c|c|c|}
\hline \multirow[t]{2}{*}{ Compounds } & \multirow[t]{2}{*}{6} & \multicolumn{2}{|c|}{$8 \cdot 0.5 \mathrm{CH}_{2} \mathrm{Cl}_{2}$} \\
\hline & & molecule A & molecule B \\
\hline \multicolumn{4}{|l|}{ Bond lengths } \\
\hline $\mathrm{Au} 1-\mathrm{C} 1 /$ & $2.003(4)$ & $2.009(4)$ & $2.009(4)$ \\
\hline \multicolumn{4}{|l|}{$\mathrm{Au} 2-\mathrm{C} 21$} \\
\hline $\mathrm{Au} 1-\mathrm{Br} 3 /$ & $2.4107(5)$ & $2.4256(5)$ & $2.4159(5)$ \\
\hline \multicolumn{4}{|l|}{$\mathrm{Au} 2-\mathrm{Br} 23$} \\
\hline $\mathrm{Au} 1-\mathrm{Br} 2 /$ & $2.4276(4)$ & $2.4109(5)$ & $2.4224(5)$ \\
\hline \multicolumn{4}{|l|}{$\mathrm{Au} 2-\mathrm{Br} 22$} \\
\hline Au1-Br1/ & $2.4465(4)$ & $2.4521(5)$ & $2.4519(5)$ \\
\hline \multicolumn{4}{|l|}{$\mathrm{Au} 2-\mathrm{Br} 21$} \\
\hline $\mathrm{N} 1-\mathrm{C} 1 /$ & $1.348(4)$ & $1.344(5)$ & $1.339(6)$ \\
\hline \multicolumn{4}{|l|}{$\mathrm{N} 21-\mathrm{C} 21$} \\
\hline N2-C1/ & $1.346(4)$ & $1.345(5)$ & $1.343(6)$ \\
\hline \multicolumn{4}{|l|}{$\mathrm{N} 22-\mathrm{C} 21$} \\
\hline \multicolumn{4}{|l|}{ Bond angles } \\
\hline $\begin{array}{l}\mathrm{C} 1-\mathrm{Au} 1-\mathrm{Br} 1 / \\
\mathrm{C} 21-\mathrm{Au} 2-\mathrm{Br} 21\end{array}$ & 179.01(10) & $178.62(12)$ & $179.82(14)$ \\
\hline $\begin{array}{l}\mathrm{Br} 3-\mathrm{Au} 1-\mathrm{Br} 2 / \\
\mathrm{Br} 23-\mathrm{Au} 2-\mathrm{Br} 22\end{array}$ & $176.43(2)$ & $176.34(2)$ & $175.25(2)$ \\
\hline $\begin{array}{l}\mathrm{C} 1-\mathrm{Au} 1-\mathrm{Br} 3 / \\
\mathrm{C} 21-\mathrm{Au} 2-\mathrm{Br} 23\end{array}$ & $87.67(10)$ & $88.71(12)$ & $87.51(12)$ \\
\hline $\begin{array}{l}\mathrm{C} 1-\mathrm{Au} 1-\mathrm{Br} 2 / \\
\mathrm{C} 21-\mathrm{Au} 2-\mathrm{Br} 22\end{array}$ & $88.82(10)$ & $87.79(12)$ & $88.01(12)$ \\
\hline $\begin{array}{l}\mathrm{N} 1-\mathrm{C} 1-\mathrm{N} 2 / \\
\mathrm{N} 21-\mathrm{C} 21-\mathrm{N} 22\end{array}$ & $108.8(3)$ & $108.7(4)$ & 109.1(4) \\
\hline
\end{tabular}


The bond angles in $\mathbf{6}$ and $\mathbf{8} \cdot 0.5 \mathrm{CH}_{2} \mathrm{Cl}_{2}$ deviate only slightly from the perfect square-planar geometry. The $\mathrm{N}-$ $\mathrm{C}_{\text {carbene }}-\mathrm{N}$ bond angles in $6\left(108.8(3)^{\circ}\right)$ and $\mathbf{8} \cdot 0.5 \mathrm{CH}_{2} \mathrm{Cl}_{2}$ $\left(108.7(4)^{\circ}\right.$ and $\left.109.1(4)^{\circ}\right)$ are slightly larger than the equivalent angles in the parent gold(I) complexes (Table 1).

\section{Conclusions}

The synthesis of gold(I) complexes of the type $[\mathrm{AuBr}(\mathrm{L})]$ and of gold(III) complexes of the type $\left[\mathrm{AuBr}_{3}(\mathrm{~L})\right]$ with $\mathrm{L}=$ benzimidazolin-2-ylidene ligands has been described. The gold(I) carbene complexes were obtained from $[\mathrm{AuCl}(\mathrm{L})]$ complexes by halide exchange with lithium bromide and the gold(III) complexes have been obtained by oxidation of $[\mathrm{AuBr}(\mathrm{L})]$ complexes with elemental bromine. The spectroscopic data for the new gold(I) and gold(III) complexes are in good agreement with equivalent data for related complexes bearing the related imidazolin-2-ylidene and imidazolidin-2-ylidene ligands. The same is true for the metric parameters of the linear complexes of the type $[\operatorname{AuBr}(\mathrm{L})]$ and the square-planar complexes of the type $\left[\mathrm{AuBr}_{3}(\mathrm{~L})\right]$.

\section{Experimental Section}

All operations were carried out in an atmosphere of dry argon by using Schlenk and vacuum techniques. Solvents were dried by standard methods and were freshly distilled prior to use. The ( $N, N$ '-dialkylbenzimidazolin-2-ylidene)gold(I) chlorides were prepared using published procedures $[16,26]$. NMR spectra were recorded on a Bruker Avance I 400 (400 MHz) spectrometer. EI mass spectra were measured on a Varian MAT 212 instrument.

General Procedure for the Synthesis of the $\left(N, N^{\prime}-\right.$ Dialkylbenzimidazolin-2-ylidene)gold(I) Bromides (1-4): A mixture of the ( $N, N^{\prime}$-dialkylbenzimidazolin-2-ylidene)gold(I) chloride $(0.3 \mathrm{mmol})$ and a tenfold excess of lithium bromide $(0.261$ $\mathrm{g}, 3.0 \mathrm{mmol})$ were dissolved in acetone $(10 \mathrm{~mL})$. The reaction mixture was stirred for $24 \mathrm{~h}$ at ambient temperature. The solvent was the removed in vacuo and the bright yellow residue was dissolved in dichloromethane $(30 \mathrm{~mL})$. The solution was dried with magnesium sulfate, filtrated and the solvent was removed in vacuo. The gold(I) complexes were purified by column chromatography (silica gel, dichloromethane), dried in vacuo and were finally obtained as a colorless solid.

( $N, N$ '-Dimethylbenzimidazolin-2-ylidene)gold(I) Bromide (1): Yield: $0.109 \mathrm{~g}, 85.7 \%$. ${ }^{1} \mathbf{H}$ NMR $\left(400.0 \mathrm{MHz}, \mathrm{CD}_{2} \mathrm{Cl}_{2}\right): \delta=7.52-$ 7.44 (m, $4 \mathrm{H}, \mathrm{Ar}-\mathrm{H}), 4.03$ (s, $\left.6 \mathrm{H}, \mathrm{NCH}_{3}\right) .{ }^{13} \mathbf{C ~ N M R}(100.6 \mathrm{MHz}$, $\left.\mathrm{CD}_{2} \mathrm{Cl}_{2}\right): \delta=133.1,124.6,111.3(\mathrm{Ar}-\mathrm{C}), 34.8\left(\mathrm{NCH}_{3}\right)$. The resonance of the carbene carbon atom was not detected. MS (EI, 20 $\left.\mathrm{eV}, 190{ }^{\circ} \mathrm{C}\right): \mathrm{m} / \mathrm{z}=424,422\left(\mathrm{M}^{+}\right), 343\left(\mathrm{M}^{+}-\mathrm{Br}\right)$.

( $N, N$ '-Diethylbenzimidazolin-2-ylidene)gold(I) Bromide (2): Yield: $0.124 \mathrm{~g}, 91.3 \%$. ${ }^{1} \mathbf{H}$ NMR $\left(400.0 \mathrm{MHz}, \mathrm{CDCl}_{3}\right): \delta=7.51-$ $7.46(\mathrm{~m}, 2 \mathrm{H}, \mathrm{Ar}-\mathrm{H}), 7.45-7.40(\mathrm{~m}, 2 \mathrm{H}, \mathrm{Ar}-\mathrm{H}), 4.52$ (q, ${ }^{3} J=7.4$ $\left.\mathrm{Hz}, 4 \mathrm{H}, \mathrm{NCH}_{2} \mathrm{CH}_{3}\right), 1.54\left(\mathrm{t},{ }^{3} \mathrm{~J}=7.4 \mathrm{~Hz}, 6 \mathrm{H}, \mathrm{NCH}_{2} \mathrm{CH}_{3}\right) .{ }^{13} \mathrm{C}$ NMR $\left(100.6 \mathrm{MHz}, \mathrm{CDCl}_{3}\right): \delta=180.5(\mathrm{NCN}), 132.7,124.5,111.4$ (Ar-C), $43.8\left(\mathrm{NCH}_{2} \mathrm{CH}_{3}\right), 15.4\left(\mathrm{NCH}_{2} \mathrm{CH}_{3}\right) . \mathrm{MS}(\mathrm{EI}, 20 \mathrm{eV}$, $\left.200{ }^{\circ} \mathrm{C}\right): \mathrm{m} / z=452,450\left(\mathbf{M}^{+}\right), 371\left(\mathbf{M}^{+}-\mathrm{Br}\right)$.

(N,N'-Dipropylbenzimidazolin-2-ylidene)gold(I) Bromide (3): Yield: $0.136 \mathrm{~g}, 94.9 \%$. ${ }^{\mathbf{H}} \mathbf{H}$ NMR $\left(400.0 \mathrm{MHz}, \mathrm{CD}_{2} \mathrm{Cl}_{2}\right): \delta=7.50$ 7.45 (m, 2 H, Ar-H), 7.43-7.39 (m, 2 H, Ar-H), 4.41 (t, ${ }^{3} J=7.3 \mathrm{~Hz}$,
$4 \mathrm{H}, \mathrm{NCH}_{2} \mathrm{CH}_{2} \mathrm{CH}_{3}$ ), 1.98 (sext, ${ }^{3} J=7.3 \mathrm{~Hz}, 4 \mathrm{H}, \mathrm{NCH}_{2} \mathrm{CH}_{2} \mathrm{CH}_{3}$ ), $0.99\left(\mathrm{t},{ }^{3} \mathrm{~J}=7.3 \mathrm{~Hz}, 6 \mathrm{H}, \mathrm{NCH}_{2} \mathrm{CH}_{2} \mathrm{CH}_{3}\right) .{ }^{13} \mathrm{C}$ NMR $(100.6 \mathrm{MHz}$, $\left.\mathrm{CD}_{2} \mathrm{Cl}_{2}\right): \delta=181.2(\mathrm{NCN}), 133.1,124.4,111.5(\mathrm{Ar}-\mathrm{C}), 50.2$ $\left(\mathrm{NCH}_{2} \mathrm{CH}_{2} \mathrm{CH}_{3}\right), 23.3\left(\mathrm{NCH}_{2} \mathrm{CH}_{2} \mathrm{CH}_{3}\right), 11.3\left(\mathrm{NCH}_{2} \mathrm{CH}_{2} \mathrm{CH}_{3}\right)$. MS $\left(\mathrm{EI}, 20 \mathrm{eV}, 120{ }^{\circ} \mathrm{C}\right): \mathrm{m} / \mathrm{z}=480,478\left(\mathrm{M}^{+}\right), 399\left(\mathrm{M}^{+}-\mathrm{Br}\right)$.

(N,N'-Dibutylbenzimidazolin-2-ylidene)gold(I) Bromide (4): Yield: $0.149 \mathrm{~g}, 97.6 \%$. ${ }^{1} \mathbf{H}$ NMR $\left(400.0 \mathrm{MHz}, \mathrm{CDCl}_{3}\right): \delta=7.49-$ 7.45 (m, 2 H, Ar-H), 7.43-7.39 (m, $2 \mathrm{H}, \mathrm{Ar}-\mathrm{H}), 4.47$ (t, ${ }^{3} J=7.4 \mathrm{~Hz}$, $\left.4 \mathrm{H}, \mathrm{NCH}_{2} \mathrm{CH}_{2} \mathrm{CH}_{2} \mathrm{CH}_{3}\right), 1.93-1.89$ (m, $4 \mathrm{H}, \mathrm{NCH}_{2} \mathrm{CH}_{2} \mathrm{CH}_{2} \mathrm{CH}_{3}$ ), 1.45-1.38 (m, $\left.4 \mathrm{H}, \mathrm{NCH}_{2} \mathrm{CH}_{2} \mathrm{CH}_{2} \mathrm{CH}_{3}\right), 0.96\left(\mathrm{t},{ }^{3} J=7.4 \mathrm{~Hz}, 6 \mathrm{H}\right.$, $\left.\mathrm{NCH}_{2} \mathrm{CH}_{2} \mathrm{CH}_{2} \mathrm{CH}_{3}\right){ }^{13} \mathbf{C}$ NMR $\left(100.6 \mathrm{MHz}, \mathrm{CDCl}_{3}\right): \delta=181.1$ (NCN), 133.0, 124.4, 111.5 (Ar-C), $48.6\left(\mathrm{NCH}_{2} \mathrm{CH}_{2} \mathrm{CH}_{2} \mathrm{CH}_{3}\right), 32.0$ $\left(\mathrm{NCH}_{2} \mathrm{CH}_{2} \mathrm{CH}_{2} \mathrm{CH}_{3}\right), \quad 20.0 \quad\left(\mathrm{NCH}_{2} \mathrm{CH}_{2} \mathrm{CH}_{2} \mathrm{CH}_{3}\right), \quad 13.7$ $\left(\mathrm{NCH}_{2} \mathrm{CH}_{2} \mathrm{CH}_{2} \mathrm{CH}_{3}\right)$. MS (EI, $\left.20 \mathrm{eV}, 160{ }^{\circ} \mathrm{C}\right): \mathrm{m} / \mathrm{z}=508,506\left(\mathrm{M}^{+}\right)$, $427\left(\mathrm{M}^{+}-\mathrm{Br}\right)$.

General Procedure for the Synthesis of the $(N, N$ '-Dialkyl benzimidazolin-2-ylidene)gold(III) Tribromides (5-8): A $(N, N$ 'dialkylbenzimidazolin-2-ylidene)gold(I) bromide 1-4 (0.25 mmol) was dissolved in dichloromethane $(10 \mathrm{~mL})$. This colorless solution was cooled down to $-78{ }^{\circ} \mathrm{C}$, and an excess of bromine $(0.03 \mathrm{ml}$, $0.6 \mathrm{mmol})$ was added to the solution of the gold(I) complex. The orange solution obtained was stirred for $2 \mathrm{~h}$ at $-78{ }^{\circ} \mathrm{C}$. Then the solvent was removed in vacuo. The orange residue was dissolved in dichloromethane $(5 \mathrm{~mL})$ and dried again in vacuo in order to remove unreacted bromine. This procedure was repeated once more. Finally, the residue was dissolved in dichloromethane (2 $\mathrm{mL})$ and this solution was added to pentane $(100 \mathrm{~mL})$. The precipitate obtained was isolated by filtration and dried in vacuo.

(N,N'-Dimethylbenzimidazolin-2-ylidene)gold(III) Tribromide (5): Yield: $0.125 \mathrm{~g}, 85.7 \%$. ${ }^{1} \mathbf{H}$ NMR $\left(400.0 \mathrm{MHz}, \mathrm{CD}_{2} \mathrm{Cl}_{2}\right): \delta=$ 7.62-7.54 (m, $4 \mathrm{H}, \mathrm{Ar}-\mathrm{H}), 4.11\left(\mathrm{~s}, 6 \mathrm{H}, \mathrm{NCH}_{3}\right) .{ }^{13} \mathbf{C}$ NMR (100.6 $\left.\mathrm{MHz}, \mathrm{CD}_{2} \mathrm{Cl}_{2}\right): \delta=146.8(\mathrm{NCN}), 134.3,125.8,111.6(\mathrm{Ar}-\mathrm{C}), 34.8$ $\left(\mathrm{NCH}_{3}\right) . \mathrm{MS}\left(\mathrm{EI}, 20 \mathrm{eV}, 160{ }^{\circ} \mathrm{C}\right): \mathrm{m} / \mathrm{z}=424,422\left(\mathrm{M}^{+}-2 \mathrm{Br}\right), 343$ $\left(\mathrm{M}^{+}-3 \mathrm{Br}\right)$.

( $N, N$ '-Diethylbenzimidazolin-2-ylidene)gold(III) Tribromide (6): Yield: $0.125 \mathrm{~g}, 82.1 \%$. ${ }^{1} \mathbf{H}$ NMR (400.0 MHz, [D 6 DMSO): $\delta$ = 7.83-7.76 (m, $2 \mathrm{H}, \mathrm{Ar}-\mathrm{H}), 7.64-7.48(\mathrm{~m}, 2 \mathrm{H}, \mathrm{Ar}-\mathrm{H}), 4.49\left(\mathrm{q},{ }^{3} J\right.$ $\left.=7.4 \mathrm{~Hz}, 4 \mathrm{H}, \mathrm{NCH}_{2} \mathrm{CH}_{3}\right), 1.46\left(\mathrm{t},{ }^{3} \mathrm{~J}=7.4 \mathrm{~Hz}, 6 \mathrm{H}, \mathrm{NCH}_{2} \mathrm{CH}_{3}\right)$. ${ }^{13} \mathrm{C}$ NMR (100.6 MHz, [D 6 DMSO): $\delta=133.4,125.5,112.3$ (ArC), $43.5\left(\mathrm{NCH}_{2} \mathrm{CH}_{3}\right), 15.2\left(\mathrm{NCH}_{2} \mathrm{CH}_{3}\right)$. The resonance of the carbene carbon signal was not detected. MS (EI, $\left.20 \mathrm{eV}, 200{ }^{\circ} \mathrm{C}\right)$ : $m / z=452,450\left(\mathbf{M}^{+}-2 \mathrm{Br}\right), 371\left(\mathrm{M}^{+}-3 \mathrm{Br}\right)$.

( $N, N$ '-Dipropylbenzimidazolin-2-ylidene)gold(III) Tribromide (7): Yield: $0.143 \mathrm{~g}, 89.4 \%$. ${ }^{1} \mathbf{H}$ NMR $\left(400.0 \mathrm{MHz},\left[\mathrm{D}_{6}\right] \mathrm{DMSO}\right): \delta$ = 8.05-7.99 (m, $2 \mathrm{H}, \mathrm{Ar}-\mathrm{H}), 7.59-7.54(\mathrm{~m}, 2 \mathrm{H}, \mathrm{Ar}-\mathrm{H}), 4.55\left(\mathrm{t},{ }^{3} J=\right.$ $7.6 \mathrm{~Hz}, 4 \mathrm{H}, \mathrm{NCH}_{2} \mathrm{CH}_{2} \mathrm{CH}_{3}$ ), 2.03 (sext, ${ }^{3} \mathrm{~J}=7.4 \mathrm{~Hz}, 4 \mathrm{H}$, $\left.\mathrm{NCH}_{2} \mathrm{CH}_{2} \mathrm{CH}_{3}\right), 0.98\left(\mathrm{t},{ }^{3} \mathrm{~J}=7.4 \mathrm{~Hz}, 6 \mathrm{H}, \mathrm{NCH}_{2} \mathrm{CH}_{2} \mathrm{CH}_{3}\right) .{ }^{13} \mathrm{C}$ NMR (100.6 MHz, [D $\left.\left.\mathrm{D}_{6}\right] \mathrm{DMSO}\right): \delta=146.6(\mathrm{NCN}), 133.5,125.4$, 112.8 (Ar-C), $49.3\left(\mathrm{NCH}_{2} \mathrm{CH}_{2} \mathrm{CH}_{3}\right), 22.0\left(\mathrm{NCH}_{2} \mathrm{CH}_{2} \mathrm{CH}_{3}\right), 10.8$ $\left(\mathrm{NCH}_{2} \mathrm{CH}_{2} \mathrm{CH}_{3}\right)$. MS (EI, $\left.20 \mathrm{eV}, 230{ }^{\circ} \mathrm{C}\right): \mathrm{m} / \mathrm{z}=640,638\left(\mathrm{M}^{+}\right)$, 480, $478\left(\mathrm{M}^{+}-2 \mathrm{Br}\right), 399\left(\mathrm{M}^{+}-3 \mathrm{Br}\right)$.

( $N, N$ '-Dibutylbenzimidazolin-2-ylidene)gold(III) Tribromide (8): Yield: $0.141 \mathrm{~g}, 84.3 \%$. ${ }^{1} \mathbf{H}$ NMR $\left(400.0 \mathrm{MHz}, \mathrm{CDCl}_{3}\right): \delta=$ 7.64.-7.48 (m, $4 \mathrm{H}, \quad \mathrm{Ar}-\mathrm{H}), 4.94\left(\mathrm{t},{ }^{3} \mathrm{~J}=7.9 \mathrm{~Hz}, 4 \mathrm{H}\right.$, $\mathrm{NCH}_{2} \mathrm{CH}_{2} \mathrm{CH}_{2} \mathrm{CH}_{3}$ ), 2.06 (quint, ${ }^{3} J=7.7 \mathrm{~Hz}, 4 \mathrm{H}$, $\mathrm{NCH}_{2} \mathrm{CH}_{2} \mathrm{CH}_{2} \mathrm{CH}_{3}$ ), 4.48 (sext, ${ }^{3} J=7.4 \mathrm{~Hz}, 4 \mathrm{H}$, $\left.\mathrm{NCH}_{2} \mathrm{CH}_{2} \mathrm{CH}_{2} \mathrm{CH}_{3}\right), 1.00\left(\mathrm{t},{ }^{3} \mathrm{~J}=7.3 \mathrm{~Hz}, 6 \mathrm{H}, \mathrm{NCH}_{2} \mathrm{CH}_{2} \mathrm{CH}_{2} \mathrm{CH}_{3}\right.$ ). ${ }^{13} \mathrm{C}$ NMR (100.6 MHz, $\left.\mathrm{CDCl}_{3}\right): \delta=149.7(\mathrm{NCN}), 133.9,125.5$, 112.1 (Ar-C), $48.5\left(\mathrm{NCH}_{2} \mathrm{CH}_{2} \mathrm{CH}_{2} \mathrm{CH}_{3}\right), 30.9\left(\mathrm{NCH}_{2} \mathrm{CH}_{2} \mathrm{CH}_{2} \mathrm{CH}_{3}\right)$, 
$20.1\left(\mathrm{NCH}_{2} \mathrm{CH}_{2} \mathrm{CH}_{2} \mathrm{CH}_{3}\right), 13.6\left(\mathrm{NCH}_{2} \mathrm{CH}_{2} \mathrm{CH}_{2} \mathrm{CH}_{3}\right) . \mathbf{M S}$ (EI, 20 $\left.\mathrm{eV}, 220{ }^{\circ} \mathrm{C}\right): \mathrm{m} / \mathrm{z}=668,666\left(\mathrm{M}^{+}\right), 506\left(\mathrm{M}^{+}-2 \mathrm{Br}\right), 426\left(\mathrm{M}^{+}-3 \mathrm{Br}\right)$.

X-ray Diffraction Studies: Diffraction data for 1, 2, 4, 6, and 8. $0.5 \mathrm{CH}_{2} \mathrm{Cl}_{2}$ were collected with a Bruker AXS APEX CCD diffractometer equipped with a rotation anode using graphitemonochromated Mo- $K_{\alpha}$ radiation $(\lambda=0.71073 \AA)$ at $153(2) \mathrm{K}$. Data were collected over the full sphere and were corrected for absorption. Data reduction was performed with the Bruker SMART [30] program package. For further crystal data details see Table 3. Structures solutions were found with the SHELXS-97 [31] package using the heavy-atom method and were refined with SHELXL-97 [32] against $F^{2}$ using first isotropic and later anisotropic thermal parameters for all non-hydrogen atoms. Hydrogen atoms were added to the structure models at calculated positions and their thermal parameters were fixed to $1.3 \mathrm{U}_{\text {eqv }}$ of the parent atom. Crystallographic data (excluding structure factors) have been deposited with the Cambridge Crystallographic Data Centre as supplementary publications nos. CCDC-778476 (1), CCDC778477 (2), CCDC-778478 (4), CCDC-778479 (6), and CCDC$778480\left(8 \cdot 0.5 \mathrm{CH}_{2} \mathrm{Cl}_{2}\right)$. Copies of these data can be obtained free of charge on application to CCDC, 12 Union Road, Cambridge CB2 1EZ, UK [Fax: +44-1223-336033; www.ccdc.cam.ac.uk./data/request/cif].

Table 3. Summary of crystallographic data for $1,2,4,6$ and $8 \cdot 0.5 \mathrm{CH}_{2} \mathrm{Cl}_{2}$.

\begin{tabular}{|c|c|c|c|c|c|}
\hline parameter & 1 & 2 & 4 & 6 & $\mathbf{8} \cdot 0.5 \mathrm{CH}_{2} \mathrm{Cl}_{2}$ \\
\hline formula & $\mathrm{C}_{9} \mathrm{H}_{10} \mathrm{~N}_{2} \mathrm{AuBr}$ & $\mathrm{C}_{11} \mathrm{H}_{14} \mathrm{~N}_{2} \mathrm{AuBr}$ & $\mathrm{C}_{15} \mathrm{H}_{22} \mathrm{~N}_{2} \mathrm{AuBr}$ & $\mathrm{C}_{11} \mathrm{H}_{14} \mathrm{~N}_{2} \mathrm{AuBr}_{3}$ & $\mathrm{C}_{15.5} \mathrm{H}_{23} \mathrm{~N}_{2} \mathrm{AuBr}_{3} \mathrm{Cl}$ \\
\hline$M_{\mathrm{r}}$ & 423.07 & 451.12 & 507.22 & 610.94 & 709.51 \\
\hline cryst size $/ \mathrm{mm}^{3}$ & $0.06 \times 0.03 \times 0.02$ & $0.38 \times 0.12 \times 0.08$ & $0.26 \times 0.09 \times 0.05$ & $0.07 \times 0.04 \times 0.03$ & $0.20 \times 0.11 \times 0.09$ \\
\hline$a / \AA$ & $20.6153(13)$ & $10.458(2)$ & $21.535(2)$ & $8.7669(7)$ & $16.9406(9)$ \\
\hline$b / \AA$ & $8.6171(6)$ & $16.433(3)$ & $8.8488(9)$ & $10.7992(9)$ & $14.9643(8)$ \\
\hline$c / \AA$ & $13.6594(9)$ & $7.1908(13)$ & $17.179(2)$ & $16.3334(13)$ & $17.3520(10)$ \\
\hline$\alpha /^{\circ}$ & 90 & 90 & 90 & 90 & 90 \\
\hline$\beta /^{\circ}$ & $124.1020(10)$ & $94.513(3)$ & 90 & $102.4610(10)$ & $111.8540(10)$ \\
\hline$\gamma /{ }^{\circ}$ & 90 & 90 & 90 & 90 & 90 \\
\hline$V / \AA^{3}$ & $2009.2(2)$ & $1232.0(4)$ & $3273.6(6)$ & $1509.9(2)$ & $4082.7(4)$ \\
\hline Z & 8 & 4 & 8 & 4 & 8 \\
\hline space group & $C 2 / c$ & $C 2 / c$ & Pbcn & $P 2_{1} / c$ & $P 2_{1} / c$ \\
\hline$D_{\text {calcd }} / \mathrm{g} \cdot \mathrm{cm}^{-3}$ & 2.797 & 2.432 & 2.058 & 2.687 & 2.309 \\
\hline$\mu / \mathrm{mm}^{-1}$ & $18.574\left(\mathrm{Mo}-K_{\alpha}\right)$ & $15.154\left(\mathrm{Mo}-K_{\alpha}\right)$ & $11.419\left(\mathrm{Mo}-K_{\alpha}\right)$ & $17.663\left(\mathrm{Mo}-K_{\alpha}\right)$ & $13.209\left(\mathrm{Mo}-K_{\alpha}\right)$ \\
\hline $2 \theta$ range $l^{\circ}$ & $4.8-63.7$ & $4.6-60.0$ & $3.8-60.0$ & $4.6-61.0$ & $2.6-58.0$ \\
\hline data collected & 12150 & 7023 & 36226 & 17968 & 44454 \\
\hline unique data, $R_{\text {int }}$ & $3278,0.0292$ & $1798,0.0422$ & $4781,0.0480$ & $4603,0.0358$ & $10858,0.0386$ \\
\hline obsd data $[I \geq 2 \sigma(I)]$ & 2806 & 1660 & 4244 & 3954 & 8202 \\
\hline$R$ (all data) & 0.0311 & 0.0256 & 0.0301 & 0.0331 & 0.0485 \\
\hline $\mathrm{w} R$ (all data) & 0.0463 & 0.0558 & 0.0568 & 0.0535 & 0.0817 \\
\hline no. of variables & 120 & 71 & 174 & 156 & 410 \\
\hline peak/hole $/ \mathrm{e} \cdot \AA^{3}$ & $0.935 /-1.026$ & $1.915 /-1.835$ & $0.603 /-2.239$ & $1.231 /-1.463$ & $1.822 /-2.119$ \\
\hline
\end{tabular}

\section{Acknowledgement}

Financial support by the Deutsche Forschungsgemeinschaft (SFB 858 and IRTG 1444) is gratefully acknowledged.

[1] a) F. E. Hahn, M. C. Jahnke, Angew. Chem. 2008, 120, 3166-3216; Angew. Chem. Int. Ed. 2008, 47, 3122-3172; b) P. de Frémont, N. Marion, S. P. Nolan, Coord. Chem. Rev. 2009, 253, 862-892; c) M. C. Jahnke, F. E. Hahn, Top. Organomet. Chem. 2010, 30, 95-129; d) O. Kaufhold, F. E. Hahn, Angew. Chem. 2008, 120, 4122-4126; Angew. Chem. Int. Ed. 2008, 47, 4057-4061.

[2] a) A. T. Normand, K. J. Cavell, Eur. J. Inorg. Chem. 2008, 2781-2800; b) R. Coberán, E. Mas-Marzá, E. Peris, Eur. J. Inorg. Chem. 2009, 1700-1716; c) M. Poyatos, J. A. Mata, E. Peris, Chem. Rev. 2009, 109, 3677-3707; d) S. DíezGonzáles, N. Marion, S. P. Nolan, Chem. Rev. 2009, 109, 3612-3676.

[3] a) A. R. Chianese, X. Li, M. C. Janzen, J. W. Faller, R. H. Crabtree, Organometallics 2003, 22, 1663-1667; b) R. A.
Kelly, III, H. Clavier, S. Giudice, N. M. Scott, E. D. Stevens, J. Bordner, I. Samardjiev, C. D. Hoff, L. Cavallo, S. P. Nolan, Organometallics 2008, 27, 202-210; c) R. Dorta, E. D. Stevens, N. M. Scott, C. Costabile, L. Cavallo, C. D. Hoff, S. P. Nolan, J. Am. Chem. Soc. 2005, 127, 2485-2495.

[4] a) C. Radloff, J. J. Weigand, F. E. Hahn, Dalton Trans. 2009, 9392-9394; b) C. Radloff, F. E. Hahn, T. Pape, R. Fröhlich, Dalton Trans. 2009, 7215-7222; c) F. E. Hahn, C. Radloff, T. Pape, A. Hepp, Organometallics 2008, 27, 6408-6410.

[5] A. Rit, T. Pape, F. E. Hahn, J. Am. Chem. Soc. 2010, 132, 4572-4573.

[6] For a recent review see: M. Yoshizawa, J. K. Klosterman, M. Fujita, Angew. Chem. 2009, 121, 3470-3490; Angew. Chem. Int. Ed. 2009, 48, 3418-3438.

[7] a) A. Prades, R. Coberán, M. Poyatos, E. Peris, Chem. Eur. J. 2008, 14, 11474-11479; b) M. T. Zamora, M. J. Ferguson, R. McDonald, M. Cowie, Dalton Trans. 2009, 7269-7287; c) N. Schneider, M. Kuck, S. Bellemin-Laponnaz, H. Wadepohl, L. H. Gade, Eur. J. Inorg. Chem. 2009, 493-500; d) J. M. Praetorius, C. M. Crudden, Dalton Trans. 2008, 4079-4094; 
e) J. M. Praetorius, M. W. Kotyk, J. D. Webb, R. Wang, C. M. Crudden, Organometallics 2007, 26, 1057-1061.

[8] a) E. Colacino, J. Martinez, F. Lamaty, Coord. Chem. Rev. 2007, 251, 726-764; b) R. H. Grubbs, Angew. Chem. 2006 , 118, 3845-3850; Angew. Chem. Int. Ed. 2006, 45, 37603765; c) H. Clavier, K. Grela, A. Kirschning, M. Mauduit, S P. Nolan, Angew. Chem. 2007, 119, 6906-6922; Angew. Chem. Int. Ed. 2007, 46, 6786-6801; d) A. Flores-Figueroa, O. Kaufhold, A. Hepp, R. Fröhlich, F. E. Hahn, Organometallics 2009, 28, 6362-6369.

[9] a) I. J. B. Lin, C. S. Vasam, Coord. Chem. Rev. 2007, 251 , 642-670; b) J. C. Garrison, W. J. Youngs, Chem. Rev. 2005, 105, 3978-4008; c) J. C. Y. Lin, R. T. W. Huang, C. S. Lee, A. Bhattacharyya, W. S. Hwang, I. J. B. Lin, Chem. Rev. 2009, 109, 3561-3598.

[10] H. M. J. Wang, I. J. B. Lin, Organometallics 1998, 17, 972 975.

[11] a) A. S. K. Hashmi, Angew. Chem. 2008, 120, 6856-6858; Angew. Chem. Int. Ed. 2008, 47, 6754-6756; b) D. A. Gorin, B. D. Sherry, F. D. Toste, Chem. Rev. 2008, 108, 3351-3378; c) A. Arcadi, Chem. Rev. 2008, 108, 3266-3325; d) Z. Li, C. Brouwer, C. He, Chem. Rev. 2008, 108, 3239-3265; e) N. D. Shapiro, F. D. Toste, Synlett 2010, 675-691.

[12] a) I. J. B. Lin, C. S. Vasam, Can. J. Chem. 2005, 83, 812825 ; b) H. G. Raubenheimer, S. Cronje, Chem. Soc. Rev. 2008, 37, 1998-2011.

[13] a) K. M. Hindi, M. J. Panzner, C. A. Tessier, C. L. Cannon, W. J. Youngs, Chem. Rev. 2009, 109, 3859-3884; b) S. Ray, R. Mohan, J. K. Singh, M. K. Samantaray, M. M. Shaikh, D. Panda, P. Ghosh, J. Am. Soc. Chem. 2007, 129, 1504215053; c) J. L. Hickey, R. A. Ruhayel, P. J. Barnard, M. V. Baker, S. J. Berners-Price, A. Filipovska, J. Am. Chem. Soc. 2008, 130, 12570-12571; d) M. V. Baker, P. J. Barnard, S. J. Berners-Price, S. K. Brayshaw, J. L. Hickey, B. W. Skelton, A. H. White, Dalton Trans. 2006, 3708-3715.

[14] a) L. Gao, M. A. Peay, D. V. Partyka, J. B. Updegraff, III, T. S. Teets, A. J. Esswein, M. Zeller, A. D. Hunter, T. G. Gray, Organometallics 2009, 28, 5669-5681; b) L. Gao, D. V. Partyka, J. B. Updegraff, III, N. Deligonul, T. G. Gray, Eur. J. Inorg. Chem. 2009, 2711-2719.

[15] a) N. Marion, S. P. Nolan, Chem. Soc. Rev. 2008, 37, 17761782 ; b) N. Marion, R. S. Ramón, S. P. Nolan, J. Am. Chem. Soc. 2009, 131, 448-449; c) A. S. K. Hashmi, A. M. Schuster, F. Rominger, Angew. Chem. 2009, 121, 8396-8398; Angew. Chem. Int. Ed. 2009, 48, 8247-8249; d) X. Zeng, R. Kinjo, B. Donnadieu, G. Bertrand, Angew. Chem. 2010, 122, 954-957; Angew. Chem. Int. Ed. 2010, 49, 942-945.

[16] H. M. J. Wang, C. Y. L. Chen, I. J. B. Lin, Organometallics 1999, 18, 1216-1223.

[17] M. V. Baker, P. J. Barnard, S. K. Brayshaw, J. L. Hickey, B. W. Skelton, A. H. White, Dalton Trans. 2005, 37-43.

[18] a) H. M. J. Wang, C. S. Vasam, T. Y. R. Tsai, S.-H. Chen, A. H. H. Chang, I. J. B. Lin, Organometallics 2005, 24, 486493; b) D. V. Partyka, T. J. Robilotto, J. B. Updegraff, III, M. Zeller, A. D. Hunter, T. G. Gray, Organometallics 2009, 28 , 795-801; c) J. Y. Z. Chiou, S. C. Luo, W. C. You, A. Bhattacharyya, C. S. Vasam, C. H. Huang, I. J. B. Lin, Eur. J. Inorg. Chem. 2009, 1950-1959; d) P. de Frémont, N. Marion, S. P. Nolan, J. Organomet. Chem. 2009, 694, 551-560.

[19] a) M. V. Baker, P. J. Barnard, S. J. Berners-Price, S. K. Brayshaw, J. L. Hickey, B. W. Skelton, A. H. White, J. Organomet. Chem. 2005, 690, 5625-5635; b) C. Böhler, D. Stein, N. Donati, H. Grützmacher, New J. Chem. 2002, 26, 1291-1295.

[20] S. Gaillard, A. M. Z. Slawin, S. P. Nolan, Chem. Commun. 2010, 46, 2742-2744.

[21] P. de Frémont, R. Singh, E. D. Stevens, J. L. Petersen, S. P. Nolan, Organometallics 2007, 26, 1376-1385.

[22] a) S. Gaillard, A. M. Z. Slawin, A. T. Bonura, E. D. Stevens, S. P. Nolan, Organometallics 2010, 29, 394-402; b) S.
Gaillard, X. Bantreil, A. M. Z. Slawin, S. P. Nolan, Dalton Trans. 2009, 6967-6971.

[23] R. Jothibasu, H. V. Huynh, L. L. Koh, J. Organomet. Chem. 2008, 693, 374-380

[24] X. Zhang, S. Gu, Q. Xia, W. Chen. J. Organomet. Chem. 2009, 694, 2359-2367.

[25] a) M. C. Jahnke, T. Pape, F. E. Hahn, Eur. J. Inorg. Chem. 2009, 1960-1969; b) F. E. Hahn, M. C. Jahnke, T. Pape, Organometallics 2007, 26, 150-154; c) F. E. Hahn, M. C. Jahnke, V. Gomez-Benitez, D. Morales-Morales, T. Pape, Organometallics 2005, 24, 6458-6463; d) M. C. Jahnke, T. Pape, F. E. Hahn, Z. Naturforsch. 2010, 65b, 341-346; e) F. E. Hahn, M. C. Jahnke, T. Pape, Organometallics 2006, 25, 5927-5936; f) F. E. Hahn, C. Holtgrewe, T. Pape, Z. Naturforsch. 2004, 59b, 1051-1053; g) H. V. Huynh, C. Holtgrewe, T. Pape, L. L. Koh, E. Hahn, Organometallics 2006, 25, 245-249; h) F. E. Hahn, L. Wittenbecher, D. Le Van, R. Fröhlich, Angew. Chem. 2000, 112, 551-554; Angew. Chem. Int. Ed. 2000, 39, 541-544; i) F. E. Hahn, C. Holtgrewe, T. Pape, M. Martin, E. Sola, L. A. Oro, Organometallics 2005, 24, 2203-2209.

[26] M. C. Jahnke, J. Paley, F. Hupka, J. J. Weigand, F. E. Hahn, Z. Naturforsch. 2009, 64b, 1456-1462.

[27] H. Schmidbaur, A. Schier, Chem. Soc. Rev. 2008, 37, 19311951.

[28] F. E. Hahn, L. Wittenbecher, R. Boese, D. Bläser, Chem. Eur. J. 1999, 5, 1931-1935.

[29] a) J. Lemke, A. Pinto, P. Niehoff, V. Vasylyeva, N. MetzlerNolte, Dalton Trans. 2009, 7063-7070; b) M. K. Samantaray, K. Pang, M. M. Shaikh, P. Ghosh, Dalton Trans. 2008, 4893-4902.

[30] SMART, Bruker AXS 2000.

[31] SHELXS-97: G. M. Sheldrick, Acta Cryst. 1990, A46, 467-473.

[32] SHELXL-97: G. M. Sheldrick, Acta Crystallogr. 2008, A64, $112-122$.

[33] ORTEP-3, L. J. Farrugia, University of Glasgow (Scotland), 1999.

Received: ((will be filled in by the editorial staff)) Published online: ((will be filled in by the editorial staff)) 
Entry for the Table of Contents
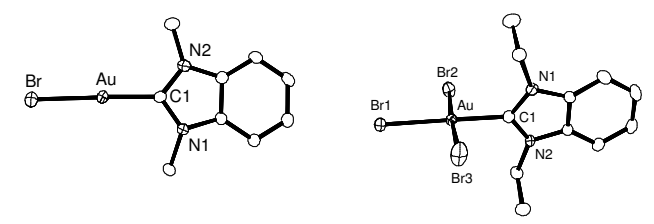

M. C. Jahnke, T. Pape and F. E. Hahn* ..... Page No. - Page No.

Synthesis and Characterization of Gold(I) and Gold(III) Complexes Derived from Benzimidazolin-2-ylidene Ligands 